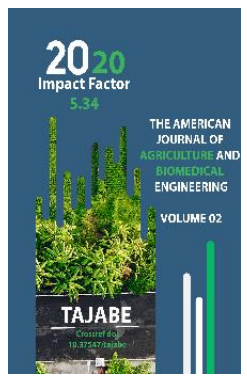

\section{Effect Of Planting Schemes On Step Height And Branching Of Peanut Varieties}

\section{Achilov Furqatbek Saparbaevich}

Ph.D. In Agriculture, Associate Professor At Tashkent State Agrarian University, Uzbekistan

Khikmatov Jamshid Bakhtiyor Ugli

Master Student, Tashkent State Agrarian University, Uzbekistan

\title{
ABSTRACT
}

In this article, information on the effect of the planting scheme on the stem height of peanut varieties is provided. The height of the stem of peanut varieties was significantly affected by the increase in the feeding area, and as the feeding area increased, the height of the plant stem also increased. The same pattern was observed in all varieties and variants used in the experiment and as the number of plant bushes decreased, the height of the stem increased, and in all varieties, the feeding rate was high at $1050 \mathrm{~cm}^{2}$ (59.9 - 59.6 - 70.2 cm). Because the varieties "Qibray-4" and "Mumtoz" are semi-erect, their stem height indicators are close to each other. Among the varieties used in the experiment, it was found that the height of the stem of "Salomat" variety was 7.9-11.4 cm higher than that of "Qibray-4" and "Mumtoz" varieties.

\section{KEYWORDS}

Peanut, planting scheme, feeding area, stem height, number of branches.

\section{INTRODUCTION}

The growth process of a plant is an indicator of crop formation depending on the existing conditions and varietal biology. Samples of peanut varieties are divided into three groups depending on the formation of the stem: the stem is erect, the stem is semi-erect, the stem is horizontal. In Central Asia, mainly peanut stalks are grown in vertical and semi-vertical varieties, the height of the stem is $35-55 \mathrm{~cm}$. Although the yield of stem-bearing varieties is very high, it is not grown in Central Asian countries due to the length of the growing 
season (180-270 days) and the complexity of inter-row cultivation. Peanut stalks and leaves are nutritious fodder for livestock, and their nutritional value is close to that of alfalfa. Peanut plant residues contain large amounts of phosphorus and potassium $[1,5]$.

\section{THE RELEVANCE OF THE PROBLEM}

In the sandy and typical gray soils of the southern regions of the Republic of Uzbekistan, scientific research was carried out by planting peanut varieties "Qibray-4", "Salomat", "Mumtoz" and "Tashkent 112" in

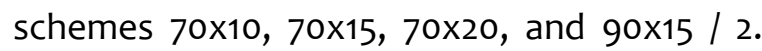
According to the results of the experiment, 150,000 seedlings per hectare of "Tashkent 112 " and "Salomat" varieties $(70 \times 10 \mathrm{~cm})$ were planted for the production of commodities on typical gray soils, the planting rate was 70-85 kg/ha, "Mumtoz" and "Qibray-4". varieties (70x15 cm) are recommended for 100-110 thousand seedlings per hectare, and the sowing rate is $80-95 \mathrm{~kg} / \mathrm{ha}$ [3].

90x15 / 2 planting scheme (150 thousand pieces/ha) is recommended for all varieties of peanuts in areas with high sandy soil slope in Surkhandarya and Kashkadarya regions. The best sowing rate is $70-85 \mathrm{~kg} / \mathrm{ha}$ for "Tashkent 112 " and "Salomat" varieties, and 105-120 kg/ha for "Mumtoz" and "Qibray-4" varieties [2].

In Central Asia, mainly walnut stalks are grown in vertical and semi-vertical varieties, the height of the stem is $35-55 \mathrm{~cm}$. Although the yield of stem-bearing varieties is very high, it is not grown in Central Asian countries due to the length of the growing season (180-270 days) and the complexity of inter-row cultivation. Peanut stalks and leaves are nutritious fodder for livestock, and their nutritional value is close to that of alfalfa. Peanut plant residues contain large amounts of phosphorus and potassium [1].

The nut plant is a highly branched plant with 4 to 20 stems on the stem. The lower branches are vigorous and can be equal to the height of the main stem. The lateral branches are erect or spreading. Based on this, the varieties can be divided according to the form of vertical growth as follows: vertical, semi-vertical, and spreading [4].

\section{RESEARCH CONDITIONS AND METHODS}

Our research was conducted in 2009-2011 in the fields of research and experimental farms of the Tashkent State Agrarian University, the impact of planting schemes on the height and branching of peanut varieties was studied. Infield experiments, 3 varieties of peanuts "Qibray-4", "Mumtoz" and "Salomat" were studied by planting in 4 planting schemes $70 \times 15-1,70 \times 20-1,70 \times 25-1$, and 70×30-1.

The experiments were performed in laboratory and field conditions. In the field experiment, the number of variants was 12 and was performed in 4 repetitions. The number of stakes is 48 . The total area of each option is 84 $\mathrm{m}^{2}$, of which the calculated area is $56 \mathrm{~m}^{2}$, ie 20 meters long and 2.8 meters wide. The surface area of one variant was $336 \mathrm{~m}^{2}$ in 4 repetitions, with a total experimental area of $4032 \mathrm{~m}^{2}$.

\section{RESEARCH RESULTS}

The main stem height of the peanut varieties studied in our scientific study was carried out in the accepted method every 15 days. When determining the main stem height of peanut varieties, it was observed that there were significant differences both in the studied varieties and in the planting scheme. (Table 1). 
According to the average 3-year data, $54.3 \mathrm{~cm}$ in the variant with a feeding area of $1050 \mathrm{~cm}^{2}$ in the variety "Qibray - 4"; $55.8 \mathrm{~cm}$ in the variant with $1400 \mathrm{~cm}^{2} ; 57.6 \mathrm{~cm}$ in the variant with 1750 $\mathrm{cm}^{2}$; The variant with $2100 \mathrm{~cm}^{2}$ was found to be $59.9 \mathrm{~cm}$. The lowest performance in this variety was observed in the variant $(54.3 \mathrm{~cm})$ with a feeding area of $1050 \mathrm{~cm}^{2}$. In the class "Mumtoz" the lowest value was observed in the variant with a feeding area of $1050 \mathrm{~cm}^{2}$, $54.0 \mathrm{~cm}$; compared to the lowest option $1.6 \mathrm{~cm}$ in the variant with a feeding area of $1400 \mathrm{~cm}^{2}$; $3.4 \mathrm{~cm}$ in the variant with feeding area 1750 $\mathrm{cm}^{2}$; was found to be $5.6 \mathrm{~cm}$ higher in the variant with a feeding area of $2100 \mathrm{~cm}^{2}$. It is noted in the table that the above pattern is preserved in this variety as well. It can be seen that the highest value was observed in the variant "Mumtoz" with a feeding area of 2100 $\mathrm{cm}^{2}(59.6 \mathrm{~cm})$. In the "Salomat" variety of peanut, the lowest feeding area was $62.2 \mathrm{~cm}$ in the variant with $1050 \mathrm{~cm}^{2}$, and $2.3 \mathrm{~cm}$ in the variant with $1400 \mathrm{~cm}^{2} ; 5.3 \mathrm{~cm}$ in the $1750 \mathrm{~cm}^{2}$ variant; It was observed that in the variant with $2100 \mathrm{~cm}^{2}$, it was $8.0 \mathrm{~cm}$ higher.

In this variety, the pattern observed in the above varieties was repeated and it was found that the maximum value was $70.2 \mathrm{~cm}$ in the variant with $2100 \mathrm{~cm}^{2}$.

Table 1

Dynamics of stem height of peanut varieties (cm)

\begin{tabular}{|c|c|c|c|c|c|c|}
\hline № & Varieties & $\begin{array}{c}\text { Planting } \\
\text { scheme }\end{array}$ & $\mathbf{2 0 0 9 y}$ & $\mathbf{2 0 1 0 y}$ & $\mathbf{2 0 1 1 y}$ & Average \\
\hline 1 & “Qibray -4" & $70 \times 15-1$ & 54,1 & 54,5 & 54,3 & 54,3 \\
\hline 2 & "Qibray -4" & $70 \times 20-1$ & 55,6 & 56,0 & 55,9 & 55,8 \\
\hline 3 & "Qibray -4" & $70 \times 25-1$ & 57,4 & 57,8 & 57,6 & 57,6 \\
\hline 4 & "Qibray -4" & $70 \times 30-1$ & 59,7 & 60,1 & 59,9 & 59,9 \\
\hline 5 & "Mumtoz" & $70 \times 15-1$ & 53,8 & 54,2 & 53,9 & 54,0 \\
\hline 6 & "Mumtoz" & $70 \times 20-1$ & 55,3 & 55,7 & 55,7 & 55,6 \\
\hline 7 & "Mumtoz" & $70 \times 25-1$ & 57,2 & 57,6 & 57,4 & 57,4 \\
\hline 8 & "Mumtoz" & $70 \times 30-1$ & 59,4 & 59,8 & 59,6 & 59,6 \\
\hline 9 & "Salomat" & $70 \times 15-1$ & 62,0 & 62,4 & 62,2 & 62,2 \\
\hline 10 & "Salomat" & $70 \times 20-1$ & 64,3 & 64,7 & 64,5 & 64,5 \\
\hline 11 & "Salomat" & $70 \times 25-1$ & 67,3 & 67,7 & 67,5 & 67,5 \\
\hline 12 & "Salomat" & $70 \times 30-1$ & 70,0 & 70,4 & 70,2 & 70,2 \\
\hline
\end{tabular}


The American Journal of Agriculture and Boimedical Engineering (ISSN - 2689-1018)

Published: December 31, 2020 | Pages: 64-69

Doi: https://doi.org/10.37547/tajabe/Volume02Issue12-11

\begin{tabular}{|c|c|c|c|c|c|}
\hline & dona & 1,0 & 0,9 & 0,9 & 0,9 \\
\cline { 2 - 6 } & $\%$ & 1,7 & 1,9 & 1,8 & 1,7 \\
\cline { 2 - 6 } NSR $_{05}$ & Varieties & 0,7 & 0,6 & 0,5 & 0,6 \\
\cline { 2 - 6 } & $\begin{array}{c}\text { Planting } \\
\text { scheme }\end{array}$ & 0,3 & 0,5 & 0,4 & 0,4 \\
\hline
\end{tabular}

In our study, it was observed that the feeding area had a significant effect on the number of branches of the peanut plant (Table 2). According to the table, "Qibray-4" and "Mumtoz" varieties belong to the Virginia branching type, and the shape of the plant is semi-branched. The stem is spreading, of medium height, the variety "Salomat" belongs to the Valencian branching type, the stem is erect, high. The results of the study show that the variety "Qibray-4" at 01.06 produced horns in all planting schemes, from 5.8 pieces/bush to 8.7 pieces/bush. It was observed that the number of branches increased to 2.9 pieces/bush in the planting scheme with a high feeding area. At 01.06, the "Mumtoz" variety produced more branches from 6.3 / bush to 9.5 / bush, ie 3.2 / bush. In the "Salomat" variety, this figure at 01.06 increased from 5.3 pieces/bush to 8.5 pieces/bush, ie 3.2 pieces/bush. As of 01.07, the "Qibray-4" variety produced 9.8 branches/bushes in the 70x15-1 planting scheme, and 13.8 bushes / 4 bushes in the 70x30-1 planting scheme.

Table 2

Number of branches of peanut varieties (2009-2011, pieces/bushes)

\begin{tabular}{|c|c|c|c|c|c|c|c|}
\hline \multirow{2}{*}{ № } & \multirow{2}{*}{ Varieties } & \multirow{2}{*}{$\begin{array}{l}\text { Planting } \\
\text { scheme }\end{array}$} & \multicolumn{5}{|c|}{ Dates } \\
\hline & & & $01 . \mathrm{VI}$ & 01.VII & 01.VIII & 01.IX & 01.X \\
\hline 1 & "Qibray - 4" & $70 \times 15-1$ & $5,8 \pm 0,6$ & $9,8 \pm 0$ & $12,1 \pm 0,17$ & $12,8 \pm 0,62$ & $12,9 \pm 1,38$ \\
\hline 2 & "Qibray - 4" & $70 \times 20-1$ & $6,8 \pm 0,78$ & $10,9 \pm 0,3$ & $13 \pm 1,49$ & $13,8 \pm 0,64$ & $13,9 \pm 0,39$ \\
\hline 3 & "Qibray - 4" & $70 \times 25-1$ & $7,9 \pm 0,71$ & $12,2 \pm 0,56$ & $14,1 \pm 1,25$ & $15 \pm 1,04$ & $15,2 \pm 0,71$ \\
\hline 4 & "Qibray - 4" & $70 \times 30-1$ & $8,7 \pm 0,7$ & $13,8 \pm 0,66$ & $15,2 \pm 1,33$ & $16 \pm 0,38$ & $16,2 \pm 0,29$ \\
\hline 5 & "Mumtoz" & $70 \times 15-1$ & $6,3 \pm 0,45$ & $10,4 \pm 0,28$ & $12,2 \pm 0,7$ & $13 \pm 0,92$ & $13,1 \pm 0,54$ \\
\hline 6 & "Mumtoz" & $70 \times 20-1$ & $7,3 \pm 0,57$ & $11,4 \pm 1,3$ & $13,4 \pm 1,28$ & $14,2 \pm 0,91$ & $14,4 \pm 0,62$ \\
\hline 7 & "Mumtoz" & $70 \times 25-1$ & $8,3 \pm 0,96$ & $12,5 \pm 1,44$ & $14,7 \pm 0,74$ & $15,4 \pm 0,72$ & $15,6 \pm 1,25$ \\
\hline
\end{tabular}


The American Journal of Agriculture and Boimedical Engineering (ISSN - 2689-1018)

Published: December 31, 2020 | Pages: 64-69

Doi: https://doi.org/10.37547/tajabe/Volume02Issue12-11

\begin{tabular}{|c|c|c|c|c|c|c|c|}
8 & “Mumtoz" & $70 \times 30-1$ & $9,5 \pm 0,26$ & $13,9 \pm 1,68$ & $16,1 \pm 1,91$ & $16,8 \pm 0,77$ & $16,9 \pm 0,62$ \\
\hline 9 & "Salomat" & $70 \times 15-1$ & $5,3 \pm 0,51$ & $7,8 \pm 0,46$ & $9,8 \pm 0,99$ & $10,5 \pm 0,01$ & $10,7 \pm 0,16$ \\
\hline 10 & "Salomat" & $70 \times 20-1$ & $6,5 \pm 0,25$ & $9,1 \pm 1,07$ & $11 \pm 1,31$ & $11,7 \pm 0,23$ & $11,8 \pm 0,11$ \\
\hline 11 & "Salomat" & $70 \times 25-1$ & $7,4 \pm 0,74$ & $10,7 \pm 0,38$ & $11,4 \pm 0,63$ & $12,2 \pm 0,78$ & $12,3 \pm 0,37$ \\
\hline 12 & "Salomat" & $70 \times 30-1$ & $8,5 \pm 0,75$ & $11,7 \pm 0,2$ & $12,4 \pm 1,45$ & $13,3 \pm 1,17$ & $13,5 \pm 1,54$ \\
\hline
\end{tabular}

In "Mumtoz" variety, as of 01.07, many branches appeared from 10.4 pieces/ bush to 13.9 pieces/ bush, ie from 3.5 / bush. By this time, the number of branches in the variety "Salomat" increased from 7.8 pieces/bush to 11.7 pieces/bush. This indicates that in a planting scheme with a high feeding area, 3.9 pieces/bush formed many horns. As of 01.08, the number of branches of the control variety "Qibray-4" is 12.1-15.2 piece/bush; 12.2-16.1 pieces/bush in "Mumtoz" variety and 9.8-12.4 pieces/bush in "Salomat" variety. At 10.09 the number of branches according to the planting scheme in the variety "Qibray - 4" is 12.8-16 pieces/bush; In "Mumtoz" variety it was increased to 13.0-16.8 pieces / bush and in "Salomat" variety to 10.5-13.3 pieces/bush. At the end of the counting of the number of branches, ie by 01.10, in the planting scheme of 70x15-1 "Qibray-4" variety it was 12.9 pieces/bush, in the planting scheme 70x30-1 with high feeding area it was 3.3 pieces/bush; In the class "Mumtoz" 13.1 pieces / bush and 3.8 pieces / bush and the variety "Salomat" 10.7 pieces / bush and up to 2.8 pieces/bush were observed. It was found that the "Salomat" variety belongs to the Valencian variety and has 2.7-3.4 fewer branches than the "Qibray-4" and "Mumtoz" varieties because the stems are erect.

\section{CONCLUSION}

The height of the stem of peanut varieties was significantly affected by the increase in the feeding area, and the height of the plant stem increased as the feeding area increased. The same pattern was observed in all varieties and variants used in the experiment, and the height of the stem increased as the number of plant bushes decreased. In all varieties had a high index when the feeding area was $1050 \mathrm{~cm}^{2}$ (59.9 - $59.6-70.2 \mathrm{~cm})$. Because the varieties "Qibray-4" and "Mumtoz" are semi-erect, their stem height indicators are close to each other. Among the varieties used in the experiment, it was found that the height of the stem of the variety "Salomat" in all variants was 7.9-11.4 cm higher than the varieties "Qibray-4" and "Mumtoz".

"Salomat" variety has less branching than "Qibray-4" and "Mumtoz" varieties (2.7-3.4 pieces/bush). Because the varieties "Mumtoz" and "Qibray-4" belong to the same Virginia branching type, the number of branches in all variants is close to each other and no significant differences were observed.

\section{REFERENCES}

1. Amanova M., X.Bo'riev, A.Rustamov. "Yeryongoq ekinining morfologik belgilarini urganish buyicha uslubiy qo'llanma 
[Methodical manual on the study of morphological features of the peanut crop]". Toshkent-2011. 26. b.

2. Amanova M., A.Rustamov. "Moyli ekinlar jahon kolleksiyasini urganish buyicha qullanma [A Guide to the Study of the World Collection of Oilseeds]". Toshkent-2010. B. 4-9.

3. Amanova M., X.Bo'riev, A.Rustamov. "Yeryongoq ekinining urugchiligi buyicha tavsiyanoma [Recommendations for the cultivation of groundnuts]". Toshkent-2010. 16. b.

4. Amanova M, Z. Xalikulov i R. Mavlyanova. «Groundnut Production in Central Asia and Caucasus Countries: Outluok for the future». 40. r. 1999.

5. Achilov F.S. «Oziqlanish maydoni va gerbisidlar meyorini maqbullashtirish asosida yeryongoq navlari hosildorligini oshirish [Improving the yield of peanut varieties based on optimization of feeding area and herbicide rates]» mavzusidagi qishloq xujaligi fanlari buyicha falsafa doktori(PhD) ilmiy darajasini olish uchun tayyorlangan dissertasiya. Tashkent. 2019. $120 \mathrm{~b}$. 